International Journal of Wireless \& Mobile Networks (IJWMN) Vol. 3, No. 2, April 2011

\title{
ANALYSIS OF CELl PHONE USAGE USING CORRELATION TECHNIQUES
}

\author{
DR. T S R MURTHY ${ }^{1}$ AND D. SIVA RAMA KRISHNA ${ }^{2}$ \\ ${ }^{1}$ Professor,Shri Vishnu Engg. College for Women,Bhimavaram. West Godavari dist,A.P,India \\ e-mail: sriram_pavan123@yahoo.co.in \\ ${ }^{2}$ Asst. professor,Swarnandhra Institute of Engg. \& Tech.,Narsapuram. West Godavari dist, \\ A.P,India \\ e-mail: srkd999@gmail.com
}

\begin{abstract}
The present paper is a sample survey analysis, examined based on correlation techniques. The usage of mobile phones is clearly almost un-avoidable these days and as such the authors have made a systematic survey through a well prepared questionnaire on making use of mobile phones to the maximum extent. These samples are various economical groups across a population of over one-lakh people. The results are scientifically categorized and interpreted to match the ground reality.
\end{abstract}

\section{KEY WORDS}

Correlation coefficient, Coefficient of Determination, Probable Error, Standard Error of Correlation coefficient.

\section{INTRODUCTION}

With the advent of communication technology, the whole world has come under one umbrella. Next to internet, cell phone has changed the life style of people and business persons in particular. The cell phone has become an indispensable tool for one and all. Right from a school going child, a house wife to a servant, the cell phone has its major impact on their lives.

Several studies have shown that mobile phone in various communities has positive as well as negative influence on Society. The cell phone is the need of every one. It is for the fact that now- a- days, having a mobile phone is a sort of necessity and it is an inevitable truth that the mobile industry is taking every one by the storm. In spite of its advantages, there are also some disadvantages of mobile phone. So it all depends on the user how he makes use of it for better living.

The Following objectives have been formulated in order to quantify various aspects that influence the use of mobile phones

- Correlation between the male and female using mobile phones.

- Correlation between the age groups of various people using the mobile phone.

- Correlation between the utilization of mobile phone with regard to the occupation of all sectors of people.

- Correlation between the maximum mobile usages of various brands by maximum number of people.

DOI : 10.5121/ijwmn.2011.3208 
International Journal of Wireless \& Mobile Networks (IJWMN) Vol. 3, No. 2, April 2011

- Correlation between the maximum purchase of mobile phones with respect to the influence made by friends, neighbors, advertisements, cell cost and similar reasons.

- Correlation between the users suffers from the battery backup.

- Correlation between the study with regard to various networks (SIM cards) utilized by the mobile users.

- Correlation among different networks (SIM cards) whether they influences the purchaser.

- Correlation between the study of net work connection with respect to pre-paid and post paid connections.

- Correlation between the monthly expenditures.

- The relation between the correlation and probable error

- Relation between the correlation and 6 times of probable error

\section{Methodology}

To satisfy the objectives of the study, qualitative methodologies along with quantitative techniques are employed. The study is in descriptive nature. A total of 2131 people were made to participate in this survey. Only 1804 of these people are using mobile phones and the remaining 327 are non-users of cell phones because of their own reasons. The survey is made, keeping in mind all classes of people such as business persons, farmers, house wives, workers, students, employees and educationalists. The survey is also made, keeping in mind different economic groups like, people of low class, middle class and high class. All the survey is made in the town of Bhimavaram as it has all types of people and business practices. The survey is made in eight different localities of Bhimavaram to meet the over all objectives of the present work.

The Primary Data was collected by the MBA students of 2009-11 Batch of Shri Vishnu Engineering College for Women, Bhimavaram. Out of 2131 people, nearly 500 high class people, 1000 middle class people and 500 low class people in the society were taken into consideration. With the help of the faculty and the students of MBA, a questionnaire is framed after detailed discussions to get holistic understanding of subject. In this paper the correlation between the eight localities with respect to the above said objectives are measured.

The Secondary Data is collected from various magazines, news papers and internet websites on different aspects of mobile phone utilization. After collecting the data from various sources, the data is subjected to verification, quantification and coding with referred coding keys. Then, the coded data is keyed into computer for data processing and analysis. The Statistical packages R, SPSS, Microsoft-Excel are used for calculation, percentage, frequency, distribution,

\section{Results and Analysis}

Correlation is a statistical tool for studying the relationship between two or more variables. Theory of correlation deals with the observation and measurement of the relationship between two or more statistical series. The study of correlation is very important from business and economic point of view.

It helps in verifying the reliability and accuracy of the data that analyses cause and effect relationship. Correlation does not necessarily mean causational. Even in the case of significant correlation, there may be no cause-and-affect connection. If a change in one variable causes a change in the other variable, is called correlation between the two variables. A change in one may be caused by or due to the other but the statistical evidence may not indicate which is cause and which is affect. Correlation may be due entirely to a third factor or several other factors 
affecting each variable, this is the case in time series. Correlation analysis involves various methods and the techniques used for studying and measuring the extent relationship between the two variables.

The figures show the joint variation among the pairs of values and give an idea of the relation ship between the two variables. If the points are scattered around a straight line, the correlation is linear and if the points are scattered around a curve, the correlation is non-linear, if the points are scattered all over without any pattern, there may not be any correlation between the variables. Two variables may have a positive correlation or negative correlation or they may be uncorrelated.

It may be noted that the all the points representing the pairs of values lie around a straight line with a positive slope. This indicates that the correlation is positive and is linear. The value of correlation coefficient lies between -1 and +1 . The value +1 implies that there is a perfect positive correlation, and the pairs of values of $\mathrm{x}$ and $\mathrm{y}$ lie on the straight line with positive slope. The value -1 implies that there is a perfect negative correlation, and the pairs of values of $\mathrm{x}$ and $y$ lie on the straight line with negative slope.

However, in real life situations, when the variables are random variables, the correlation coefficient does not equal the value $1(+1$ or -1$)$. Its value nearing 1 , indicates strong linear relationship and its value nearing 0 indicates absence of linear relationship.

Thus the zero value of correlation coefficient does not imply that there is no relationship between the two variables or they are independent of each other. However, if two variables are independent of each other then the correlation coefficient is zero.

There is interesting feature about interpretation of the low/high values of correlation and the extent of linear relationship.

In general, to have confidence in the interpretation of the value of correlation, one should have a good number of observations.

Significant relationship exists only when correlation coefficient is greater than 0.7 , when it is greater than or equal to 0.9 then the relationship between the two variables is highly significant, since coefficient of determinant is greater than or equal to 0.81 . If the correlation coefficient is less than the probable error then there is no evidence of relationship between the variables (i.e., there is no significant relationship between the variables). If the correlation coefficient is greater than six times the probable error then it is considered as a significant relationship between the variables.

- Regarding the mobile phone users, the correlation between the males and females is 0.86 , shown that there is a very high degree of correlation between the males and female.

- With respect to age groups concern, the age groups 20-40 and 40-60 show a highest degree of correlation of mobile users which is 0.89 . and the next highest is 0.79 between the age groups less than 20 and 20-40. The least is found with less than 20 years and greater than 60 years age group. It is shown in the table 1, and from figure1, we observe that the correlation between the age group 20-40 and 40-60 is highly significant and there is a positive correlation between them. 
- Regarding the occupation, the correlation between the business people and employees is 0.84 ; this is also a very high degree of correlation between the business men and employees.

- With regard to mobile companies, correlation between various brands with a target brand $A$ is measured, since brand $A$ is the leading of all the remaining brands as observed from the table 1. In this, correlation between brand $A$ and brand $B$ is the highest degree of correlation which is 0.93 . From figure 2 , it is observe that the correlation between the mobiles $A$ and $B$ is highly significant i.e., the two variables are correspondingly change.

- It can also observed that the correlation between brand $A$ and brand $F$ is 0.88 which is the next highest correlation, and the lowest correlation between brand $A$ and brand $C$ is 0.33 . i.e., the correlation between the mobiles $A$ and $C$ is very poor, this shows in figure 3 , there is a change in one variable then the corresponding change in the other variable is very slow. This may be due to several reasons, the brand $C$ may not be lucrative, may not provide more service options, may not possess more features. As such, it cannot reach more public.

- Regarding the brands of mobiles $A \& B ; A \& E ; A \& G$, the relation between correlation and probable error; correlation and 6 times probable error are found significant.

- In sales point of view, Correlation between Advertisement and cell cost is 0.84 that shows a high degree of association between the advertisements and cell cost. And the correlation between the cell cost and others is 0.71 . From these two, it is observed that cell cost plays a major influence in sales of the mobile phone.

- Regarding the battery back-up of cell phone, the correlation between the Average and Good is 0.63 , which is also a high degree of correlation, and the lowest correlation is 0.21 between Average and Poor battery backup.

- Regarding sales of network, it is observed from the table 1, the brand a is taking a leading role when compared to the remaining brands, only with a percentage of about 36 . Correlation between various brands with brand $a$ is measured, for brand $a$ is the leading of all the remaining brands. In this, correlation between brand $a$ and brand $b$ is the highest degree of correlation which is 0.93 . From figure 4, it is observe that, even though there is an evidence of correlation between a and $b$, for some values of $a$, the other variable $\mathrm{b}$ maintains silence. And the next highest is correlation between brand $a$ and brand $c$ is 0.92 , and for remaining brands with brand $a$ is also high. And the lowest of all these with brand $a$ is 0.42 the correlation between $a$ and $i$. From figure 5, it is observe that the correlation between the networks $a$ and $i$ is poor, i.e., if the change in one variable there is a poor change in the other variable. The low correlation with brand $i$ network may be attributed to its less coverage and weak signal strength.

- It has been observed that from table 1, the relation between (regarding the variables $a$ and $b$ ) correlation and probable error; correlation and 6 times of probable error is significant. Also observed that from table1, the correlation and probable error; correlation and 6 times of probable error the relation is insignificant.

- Considering the sales of network, the correlation between advertisement and call cost is 0.41 which is a low degree of correlation between them. And the correlation between call cost and others is 0.59 which is a high degree of correlation. In this the call cost plays a major role in choosing the networks by the users and this is shown in the table 1 . The maximum number of users purchased cell phones at their own discretion.

- The correlation between the prepaid and post paid connections is 0.83. The majority of mobile users are pre-paid customers with a percentage of nearly 80. 
International Journal of Wireless \& Mobile Networks (IJWMN) Vol. 3, No. 2, April 2011

- Finally, regarding monthly expenditure of the mobile users, the highest degree of correlation between 'less than Rs.300' and 'Rs.300-600 customers' is 0.96 from the figure 6 , it is observed that there is a corresponding change between the two variables. and the lowest degree of all these, the correlation between Rs.300-600 and Rs 600-1200 is 0.71 .

- It is evident that from table 1 , the relation between (regarding the variables $<300$ and 300-600; $<300$ and >600) correlation and probable error; correlation and 6 times of probable error is significant. Also it is observed that from table1, the correlation and probable error; correlation and 6 times of probable error the relation is insignificant regarding 300-600 and 600-1200.

Table 1.

\begin{tabular}{|c|c|c|c|c|c|c|c|c|c|c|c|c|c|c|}
\hline \multicolumn{10}{|c|}{ Gender } & Correlation & S.E (r) & P.E(r) & 6.P.E & Remarks \\
\hline Male & 295 & 117 & 94 & 140 & 125 & 167 & 181 & 147 & 1266 & \multirow{2}{*}{0.865} & \multirow{2}{*}{0.089} & \multirow{2}{*}{0.06} & \multirow{2}{*}{0.36} & \multirow{2}{*}{ Significant } \\
\hline Female & 208 & 107 & 79 & 120 & 79 & 78 & 119 & 75 & 865 & & & & & \\
\hline \multicolumn{10}{|c|}{ Age } & $\begin{array}{c}\mathrm{C}(<20 \& 20 \\
-40,>60)\end{array}$ & & & & \\
\hline$<20$ & 80 & 20 & 18 & 18 & 33 & 36 & 36 & 35 & 276 & & 0.134 & 0.09 & 0.54 & Significant \\
\hline $20-40$ & 223 & 127 & 53 & 60 & 60 & 136 & 184 & 140 & 983 & 0.7887 & 0.277 & 0.187 & 1.123 & $\begin{array}{c}\begin{array}{c}\text { Insignifica } \\
\text { nt }\end{array} \\
\end{array}$ \\
\hline$>60$ & 11 & 8 & 7 & 6 & 4 & 7 & 11 & 13 & 67 & 0.4644 & 0.071 & 0.48 & 0.287 & Significant \\
\hline $20-40$ & 223 & 127 & 53 & 60 & 60 & 136 & 184 & 140 & 983 & $\begin{array}{c}\mathrm{C}(20- \\
40 \& 40-60) \\
\end{array}$ & & & & \\
\hline $40-60$ & 105 & 65 & 37 & 52 & 37 & 49 & 69 & 64 & 478 & 0.8939 & 0.071 & 0.048 & 0.287 & Significant \\
\hline \multicolumn{10}{|c|}{ Occupation } & & & & & \\
\hline Business & 156 & 66 & 51 & 43 & 41 & 79 & 80 & 67 & 583 & \multirow{2}{*}{0.8348} & & & & \\
\hline employees & 100 & 48 & 41 & 53 & 40 & 73 & 89 & 42 & 486 & & 0.107 & 0.072 & 0.433 & Significant \\
\hline$F / W$ & 57 & 34 & 7 & 33 & 16 & 38 & 37 & 25 & 247 & \multirow{2}{*}{0.4964} & \multirow{2}{*}{0.266} & \multirow{2}{*}{0.179} & \multirow{2}{*}{1.078} & $\begin{array}{c}\text { Insignifica } \\
\text { nt }\end{array}$ \\
\hline others & 106 & 72 & 16 & 7 & 37 & 38 & 94 & 118 & 488 & & & & & \\
\hline \multicolumn{10}{|c|}{ Mobile company } & $\begin{array}{c}\mathrm{C}(\mathrm{A} \& \mathrm{~B}, \mathrm{C}, \\
\mathrm{D}, \mathrm{F}, \mathrm{G})\end{array}$ & & & & \\
\hline A & 244 & 115 & 61 & 71 & 76 & 142 & 182 & 135 & 1026 & \multirow{2}{*}{0.9269} & & & & \\
\hline $\mathrm{B}$ & 43 & 25 & 8 & 12 & 12 & 29 & 25 & 30 & 184 & & 0.049 & 0.033 & 0.201 & Significant \\
\hline $\mathrm{C}$ & 14 & 9 & 12 & 12 & 9 & 6 & 14 & 8 & 84 & 0.333 & 0.314 & 0.212 & 1.2 & $\begin{array}{c}\text { Insignifica } \\
\text { nt }\end{array}$ \\
\hline D & 33 & 28 & 13 & 18 & 14 & 12 & 21 & 17 & 156 & 0.6781 & 0.191 & 0.129 & 0.774 & $\begin{array}{c}\text { Insignifica } \\
\text { nt }\end{array}$ \\
\hline $\mathrm{E}$ & 25 & 17 & 9 & 6 & 6 & 9 & 9 & 11 & 92 & 0.7405 & 0.159 & 0.107 & 0.645 & Significant \\
\hline $\mathrm{F}$ & 11 & 6 & 2 & 2 & 3 & 14 & 3 & 11 & 52 & 0.5789 & 0.234 & 0.158 & 0.95 & $\begin{array}{c}\text { Insignifica } \\
\text { nt }\end{array}$ \\
\hline G & 49 & 20 & 10 & 15 & 14 & 16 & 46 & 40 & 210 & 0.8768 & 0.081 & 0.055 & 0.33 & Significant \\
\hline \multicolumn{10}{|c|}{ Influenced Factors } & \multirow{2}{*}{$\begin{array}{l}\text { C(Mob } \\
\text { Cost \& } \\
\text { Advert, } \\
\text { others) }\end{array}$} & & & & \\
\hline $\begin{array}{c}\text { Mobile } \\
\text { cost }\end{array}$ & 108 & 28 & 1 & 14 & 14 & 62 & 20 & 17 & 264 & & & & & \\
\hline Advertise & 94 & 34 & 15 & 24 & 13 & 42 & 61 & 34 & 272 & 0.844 & 0.101 & 0.068 & 0.412 & Significant \\
\hline Others & 172 & 104 & 82 & 78 & 98 & 94 & 86 & 140 & 854 & 0.718 & 0.101 & 0.067 & 0.407 & Significant \\
\hline \multicolumn{10}{|c|}{ Battery Back up } & $\begin{array}{c}\text { C(Advt\&goo } \\
\text { d,poor) }\end{array}$ & & & & \\
\hline Average & 63 & 70 & 10 & 19 & 22 & 42 & 40 & 58 & 324 & & & & & \\
\hline Good & 328 & 140 & 85 & 109 & 99 & 173 & 238 & 176 & 1348 & 0.631 & 0.212 & 0.143 & 0.861 & $\begin{array}{c}\begin{array}{c}\text { Insignifica } \\
\text { nt }\end{array} \\
\end{array}$ \\
\hline Poor & 28 & 10 & 20 & 8 & 13 & 13 & 22 & 18 & 132 & 0.217 & 0.336 & 0.227 & 1.363 & $\begin{array}{c}\begin{array}{c}\text { Insignifica } \\
\text { nt }\end{array} \\
\end{array}$ \\
\hline \multicolumn{10}{|c|}{ Networks } & $\begin{array}{c}\text { C(a\&b,c,d, } \\
\text { e,f,g,h,i) }\end{array}$ & & & & \\
\hline
\end{tabular}


International Journal of Wireless \& Mobile Networks (IJWMN) Vol. 3, No. 2, April 2011

\begin{tabular}{|c|c|c|c|c|c|c|c|c|c|c|c|c|c|c|}
\hline $\mathrm{a}$ & 151 & 69 & 41 & 51 & 42 & 89 & 115 & 80 & 638 & & & & & \\
\hline $\mathrm{b}$ & 34 & 10 & 9 & 9 & 9 & 20 & 17 & 18 & 126 & 0.926 & 0.05 & 0.034 & 0.204 & Significant \\
\hline c & 66 & 50 & 16 & 19 & 18 & 48 & 53 & 42 & 312 & 0.915 & 0.057 & 0.038 & 0.233 & Significant \\
\hline $\mathrm{d}$ & 41 & 30 & 18 & 16 & 18 & 11 & 27 & 23 & 184 & 0.715 & 0.172 & 0.116 & 0.699 & Significant \\
\hline $\mathrm{e}$ & 25 & 14 & 9 & 16 & 12 & 13 & 14 & 15 & 118 & 0.791 & 0.132 & 0.089 & 0.536 & Significant \\
\hline $\mathrm{f}$ & 36 & 17 & 7 & 6 & 6 & 13 & 8 & 19 & 112 & 0.773 & 0.142 & 0.095 & 0.575 & Significant \\
\hline $\mathrm{g}$ & 8 & 0 & 2 & 2 & 2 & 0 & 3 & 4 & 21 & 0.679 & 0.19 & 0.128 & 0.768 & $\begin{array}{c}\text { Insignifica } \\
\mathrm{nt}\end{array}$ \\
\hline $\mathrm{h}$ & 47 & 23 & 10 & 16 & 19 & 28 & 60 & 43 & 246 & 0.84 & 0.104 & 0.07 & 0.422 & Significant \\
\hline $\mathrm{i}$ & 11 & 7 & 3 & 1 & 8 & 6 & 3 & 8 & 47 & 0.478 & 0.272 & 0.184 & 1.104 & $\begin{array}{c}\text { Insignifica } \\
\text { nt }\end{array}$ \\
\hline \multicolumn{10}{|c|}{ Influenced Factor } & \multirow{2}{*}{$\begin{array}{c}\text { C(Advt\& } \\
\text { Cc,Others) }\end{array}$} & & & & \\
\hline Advertise & 20 & 27 & 14 & 9 & 8 & 17 & 10 & 23 & 128 & & & & & \\
\hline Call Cost & 197 & 54 & 17 & 19 & 48 & 131 & 84 & 108 & 658 & 0.4049 & 0.295 & 0.199 & 1.197 & $\begin{array}{c}\text { Insignifica } \\
n t\end{array}$ \\
\hline Others & 127 & 97 & 68 & 88 & 76 & 65 & 86 & 101 & 708 & 0.5934 & 0.229 & 0.154 & 0.927 & $\begin{array}{c}\text { Insignifica } \\
\mathrm{nt}\end{array}$ \\
\hline \multicolumn{10}{|c|}{ Connections } & & & & & \\
\hline Prepaid & 305 & 192 & 97 & 106 & 102 & 189 & 230 & 218 & 1439 & & & & & \\
\hline Postpaid & 114 & 28 & 18 & 30 & 32 & 39 & 70 & 34 & 365 & 0.8319 & 0.108 & 0.073 & 0.44 & $\begin{array}{c}\text { Significan } \\
t\end{array}$ \\
\hline \multicolumn{10}{|c|}{ Monthly Expenditure } & \multirow{2}{*}{\multicolumn{2}{|c|}{$\begin{array}{c}\mathrm{C}(<300 \& 3 \\
00- \\
600,>1200)\end{array}$}} & & & \\
\hline$<300$ & 184 & 119 & 52 & 64 & 88 & 144 & 113 & 52 & 816 & & & & & \\
\hline $300-600$ & 114 & 70 & 42 & 45 & 58 & 75 & 75 & 25 & 504 & 0.9639 & 0.025 & 0.016 & 0.101 & $\begin{array}{c}\text { Significan } \\
\mathrm{t}\end{array}$ \\
\hline$>1200$ & 48 & 8 & 18 & 6 & 25 & 31 & 28 & 6 & 170 & 0.8029 & 0.125 & 0.084 & 0.509 & $\begin{array}{c}\text { Significan } \\
t\end{array}$ \\
\hline $300-600$ & 114 & 70 & 42 & 45 & 58 & 75 & 75 & 25 & 504 & $\begin{array}{c}\mathrm{C}(300- \\
600 \& 600- \\
1200)\end{array}$ & & & & \\
\hline $600-1200$ & 73 & 23 & 24 & 19 & 57 & 50 & 36 & 32 & 170 & 0.7089 & 0.176 & 0.118 & 0.712 & $\begin{array}{c}\text { Insignifica } \\
\text { nt }\end{array}$ \\
\hline
\end{tabular}

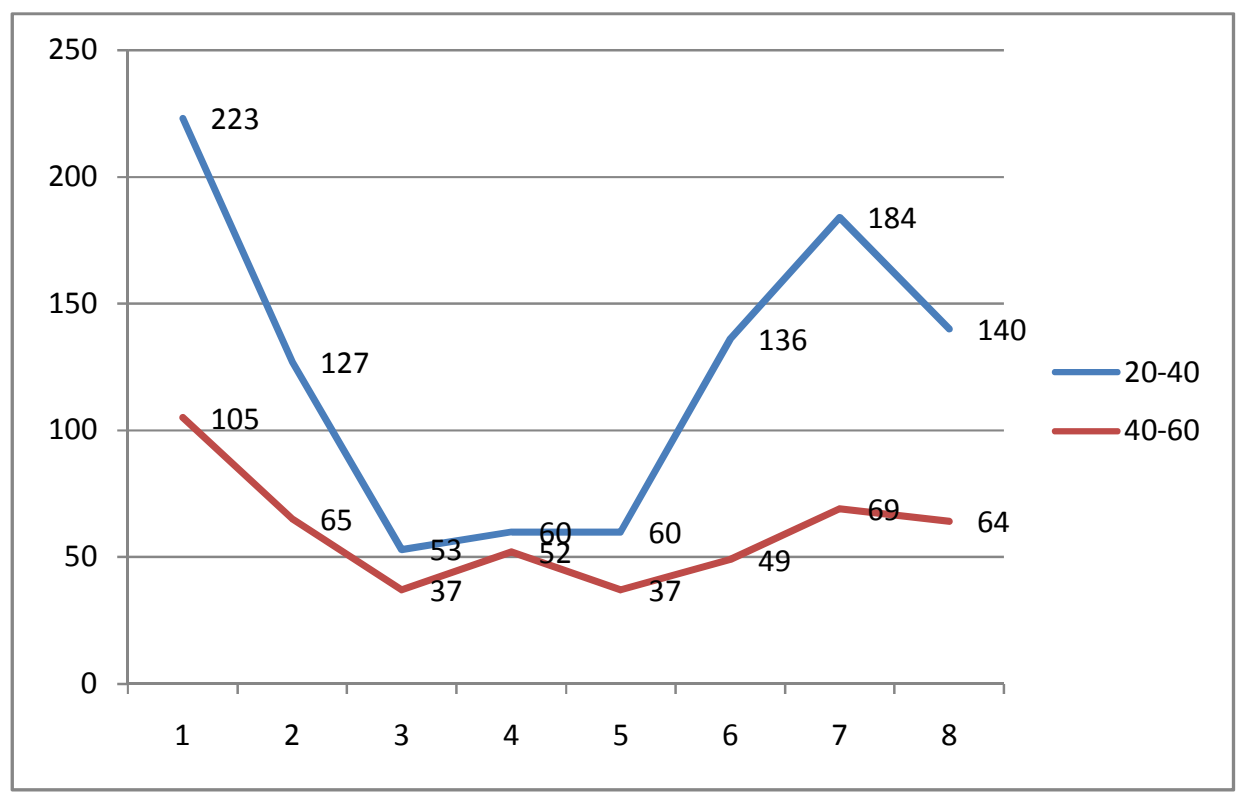

Figure 1: The correlation between the age groups $20-40$ and $40-60$ 
International Journal of Wireless \& Mobile Networks (IJWMN) Vol. 3, No. 2, April 2011

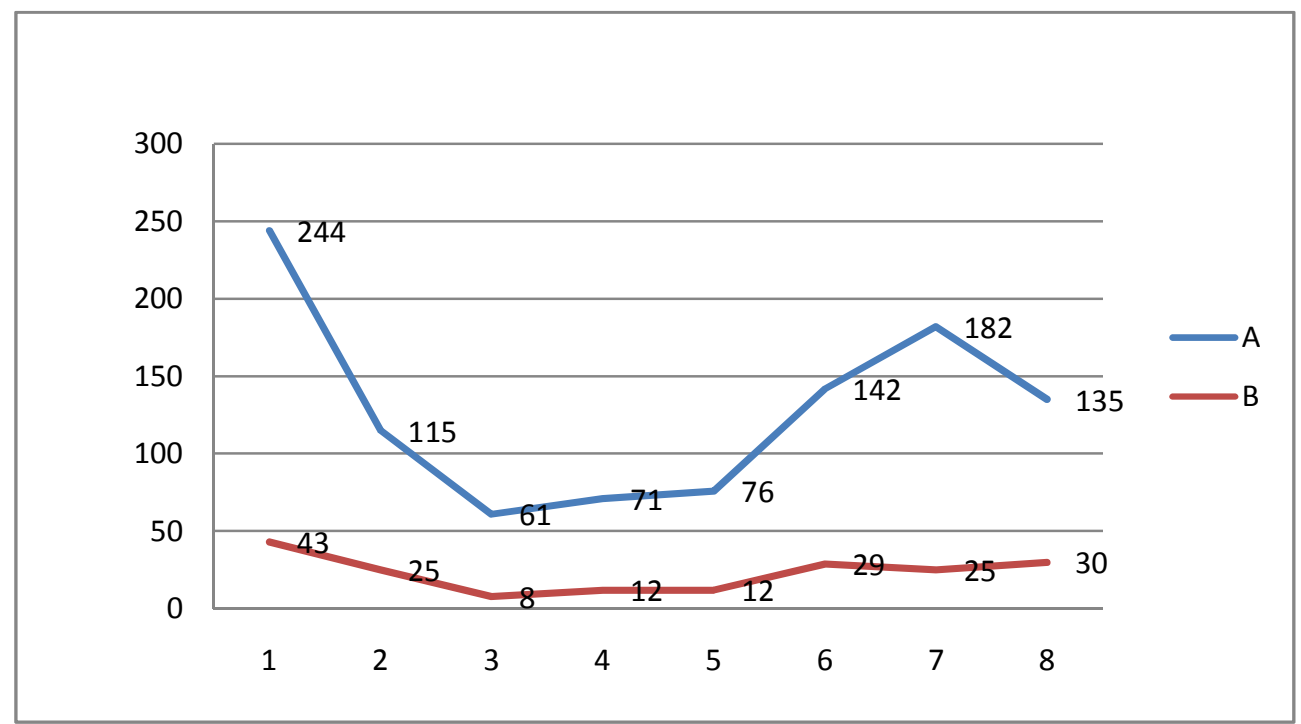

Figure 2: The correlation between the mobile companies $A$ and $B$

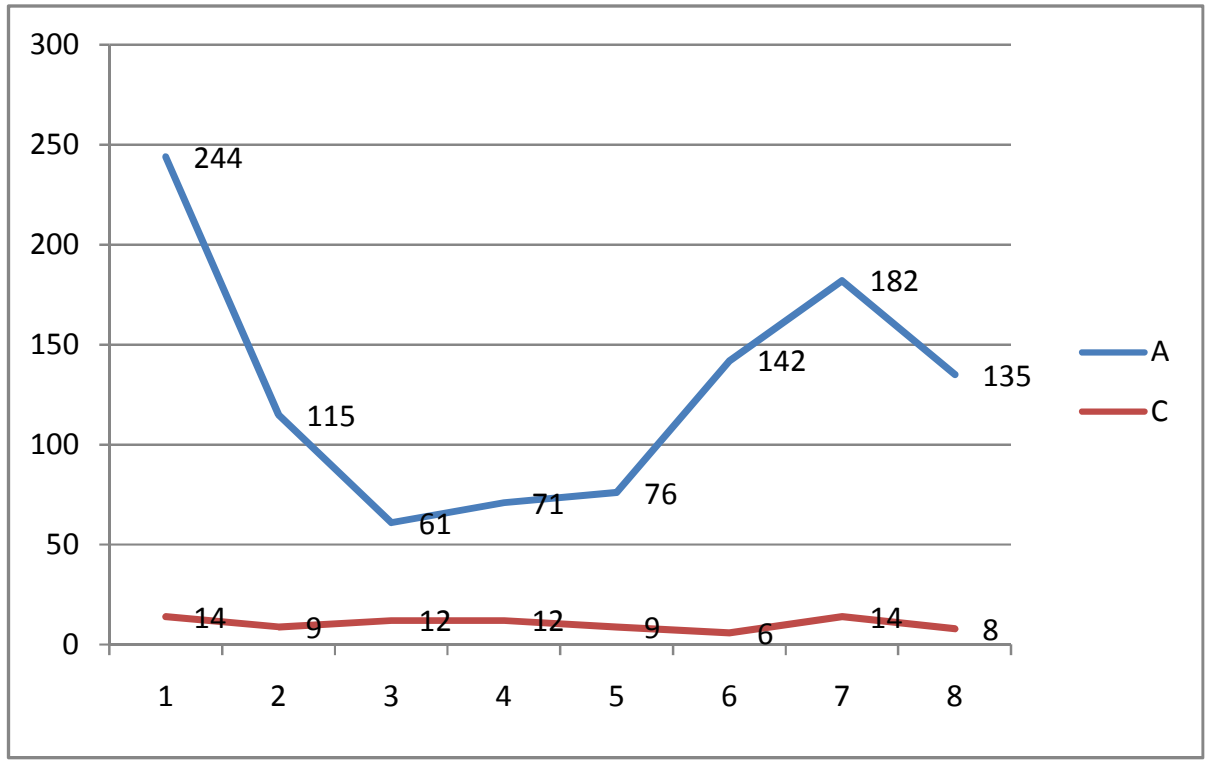

Figure 3: The correlation between the mobile companies $A$ and $C$ 
International Journal of Wireless \& Mobile Networks (IJWMN) Vol. 3, No. 2, April 2011

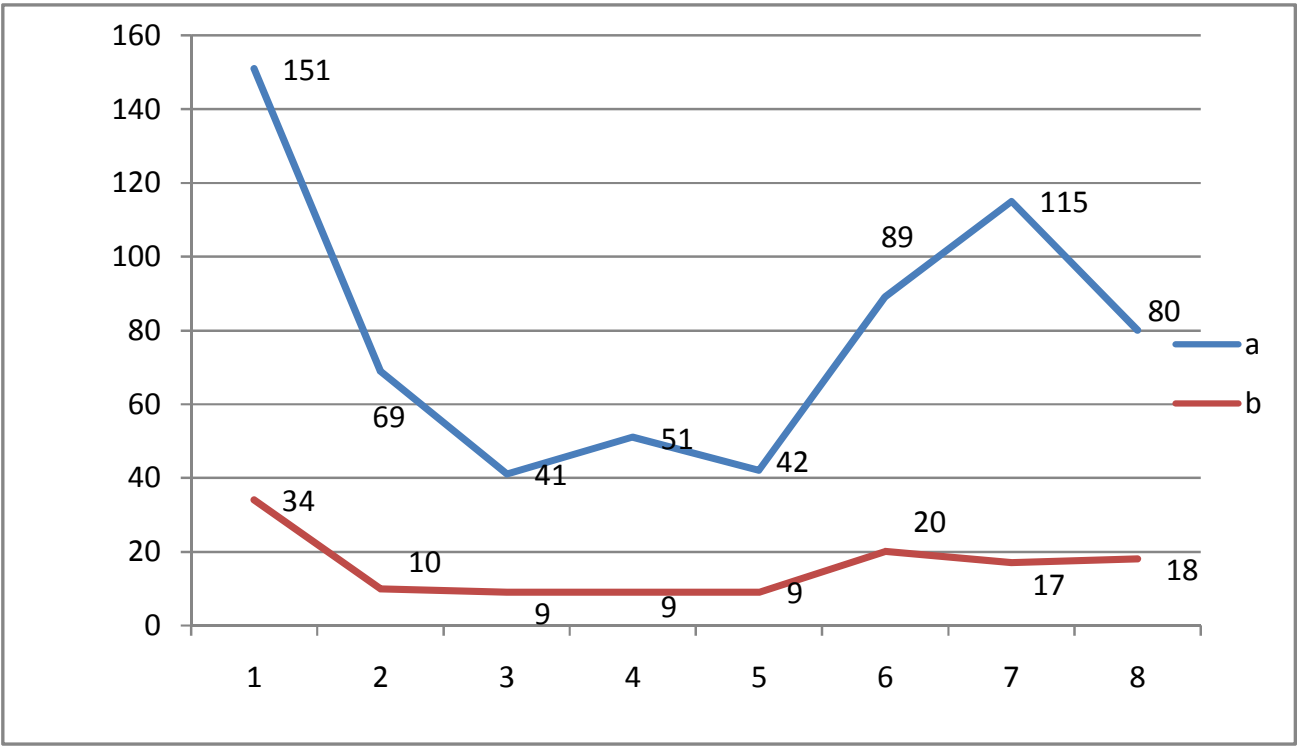

Figure 4: The correlation between networks $a$ and $b$

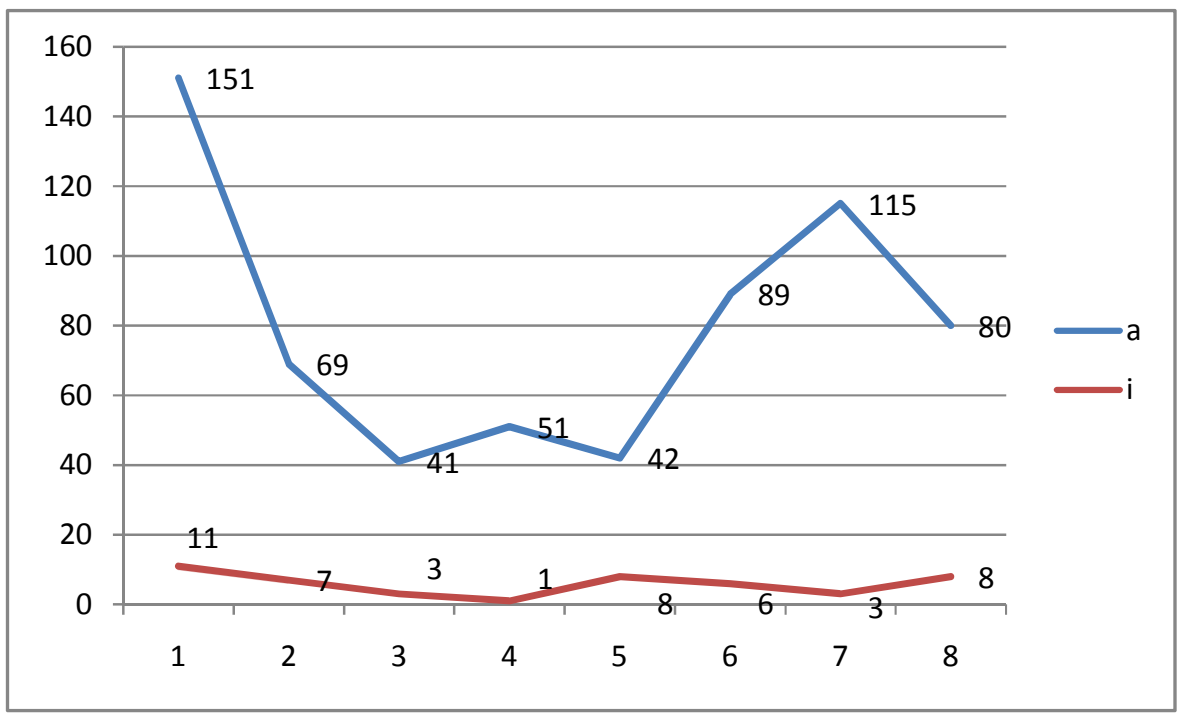

Figure 5: The correlation between the networks $a$ and $i$ 


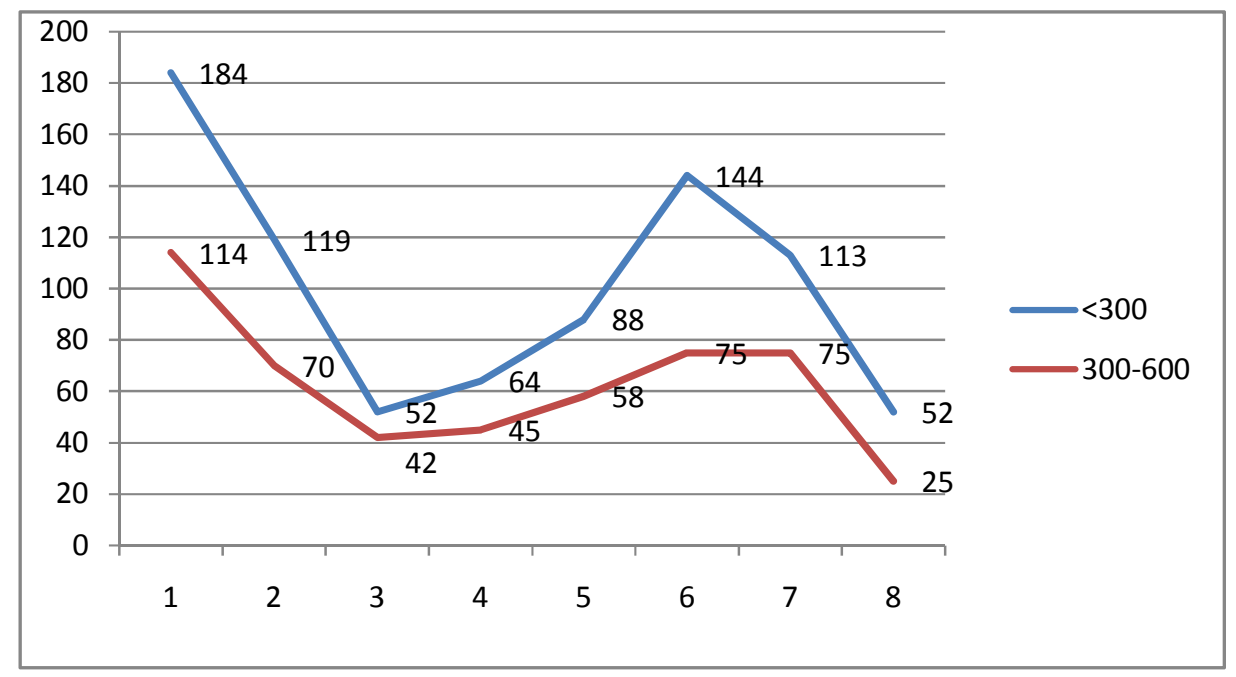

Figure 6: The correlation between the monthly expenditure Rs $<300$ and Rs.300-600

\section{Conclusions}

The study of correlation is of immense use in practical life. Correlation measures the degree or strength of the linear relationship between the variables. With the help of correlation analysis one can identify the direction or nature of relationship between variables. Probable error of the correlation coefficient is applicable for the measurement of reliability of the computed value of the correlation coefficient. If the correlation coefficient is greater than six times the probable error then it is considered as a significant relationship between the variables. With this analysis, we can measure the magnitude or degree of relationship existing between the variables. Cell phone is being widely used for many valid reasons. The usage of it varies from one age group to the other. Investigation has proved that majority of users are men. Business persons and employees are also using the cell phones more than the others. There is only one mobile company 'Brand- $A$ ' which is selling the maximum number of cell phones and is far ahead of others. The people who are buying it are very intelligent and taking their own decisions in the choice of cell phones. The other factors like friends, neighbors, cell cost and advertisements are less influencing factors in the purchase of cell phones. The people that have been taken into account are both mobile users and non-mobile users. Out of this number, a negligible or a very few percentage of people is not using the cell phone for their own reasons.

People are also selecting network connections with different options in mind. Prepaid connection has influenced the most mobile users. Majority users have optimized with regard to the usage of cell phone. The minimum expenditure is less than Rs.300/- per month. Only less percentage of the users spends more than Rs.1200/- per month.

Though the study is restricted to a particular town the samples are known to interviewers closely. Another serious study is required with larger sample size so that important factors other than these may be found which influence the society to use mobiles so frequently.

\section{ACKNOWLEDGEMENTS}

The authors are thankful to the students of Shri Vishnu Engineering College for Women, 2009-2011 batch of MBA for their cooperation in collecting the data, and also thankful to their managements to provide necessary facilities. 
International Journal of Wireless \& Mobile Networks (IJWMN) Vol. 3, No. 2, April 2011

\section{REFERENCES}

[1] Gangadhar B.Sonar and Santosh M.Jainapur(2006)-“Impact of Mobile Phone usage on academic Environment:A Study from Management Perspective”.(Vol.2No.3 Oct 2006 Issue of Journal of Global Economy, Mumbai).

[2] Fraunholz B and unnithan C (2004) critical success factors in mobile communication:A comparative roadmap for germony and india international journal of mobile communication,Vol.2.,No.1.pp.87-101

[3] Merisavo M,Vesanen J, Arpponen Aet al (2006), "The Effectiveness of Targeted Mobile Advertising in Selling Mobile Services: An Empirical Study International Journel of Mobile Communications,Vol-4,No.2,PP.119-127.

[4] Singh Fulbag and Sharma Reema(2007), ’Cellular Services and Consumer Buying Behaviour in Amritsar City ,The IUP Journel of Consumer Behaviour ,Vol.2,No.3,PP.39-51.

[5] D. Estrin, R. Govindan, J. Heidemann, and S. Kumar, "Next century challenges: Scalable coordination in sensor networks", in Proceedings of ACM Mobicom, Seattle, Washington, USA, August 1999, pp 263-- 270, ACM.

[6] I.F. Akyildiz, W. Su, Y. Sankarasubramaniam and E. Cayirci, "A Survey on Sensor Networks", IEEE

Communications Magazine, pp. 102--114, August 2002.

[7] D. Estrin, L. Girod, G. Pottie, M. Srivastava, "Instrumenting the world with wireless sensor networks", In Proceedings of the International Conference on Acoustics, Speech and Signal Processing (ICASSP 2001.

[8] L. M. S. D. Souza, H. Vogt and M. Beigl, "A survey on fault tolerance in wireless sensor networks",2007.

9] T.N. Srivastava, Shailaja Rego “Statistics for Management” - Tata Mc Graw-Hill

[10] Barry Render, Ralph M. Stair, JR, Michael. E. Hanna “ Quantitative analysis for Management Pearson education, $9^{\text {th }}$ edition.

\section{Authors}

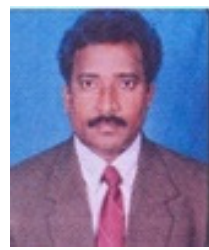

${ }^{1}$ Dr. T.S.R. Murthy completed M.Sc., (Statistics), Andhra University, Visakhapatnam and Ph.D. (Operations Research), Andhra University, Visakhapatnam and at present working as Professor of Mathematics at Shri Vishnu Engineering College for Women, Bhimavaram. He has nearly 20 years of teaching experience for B.Sc., B.Tech, M.C.A., M.B.A., Pharmacy, etc., students. He is also handling classes for competitive examinations. T.S.R. Murthy has published several papers in reputed journals. He is also authoring some books. He is a life member of Indian Society of Technical Education. He is an active participant in various faculty development programs

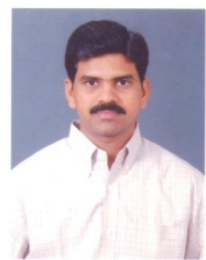

${ }^{2}$ D.S.R.Krishna completed M.Sc., (Pure Mathematics), Andhra University and M.Phil (Pure Mathematics), Alagapa University and (Ph.D) pursuing and at present working as Asst.Professor of Mathematics at Swarnandhra Institute of Engineering \& Technology , Narsapuram. He has nearly 12 years of teaching experience for B.Sc., B.Tech, M.C.A., M.B.A., M.Sc , etc., students. He research interests are in areas of Operations Research, Queueing Models, Orthomodular lattices 